\title{
Distribution extension of Strabomantis ruizi (Lynch, 1981) (Amphibia, Anura, Strabomantidae) from the department of Valle del Cauca, Colombia
}

\author{
Jorge Horacio Velandia-Perilla*, Ana Paola Yusti-Muñoz and Wilmar Bolívar-G \\ Universidad del Valle, Departamento de Biología, Grupo de Investigación en Ecología Animal. Calle 13 \# 100 - 00, Sede Meléndez. A.A 25360 Cali \\ Colombia \\ * Corresponding author. E-mail: jorgehvelandia@gmail.com
}

\begin{abstract}
Strabomatis ruizi is a large-sized frog from the Andean cloud forest of Cordillera Occidental, department of Valle del Cauca, Colombia. We present two new records for Strabomantis ruizi on the eastern slope of Cordillera Occidental,Valle del Cauca, Colombia.
\end{abstract}

Strabomantis ruizi (Lynch, 1981) is a large frog (snoutvent length SVL = 29.8-45.1 $\mathrm{mm}$ in adult males, and 59.7$70.0 \mathrm{~mm}$ in adult females; Lynch 1997) (Figure 1) that belongs to the Strabomantis sulcatus species-group (Lynch 1997). The description of this species was based on a single juvenile female from Reserva Forestal de Yotoco, Valle del Cauca, Colombia. Strabomantis ruizi is characterized by having a wide head, dorsal skin shagreened and bearing numerous subconical warts, a pair of folds extending from upper eyelid to posterior level of suprascapulae, and skin of upper surface of limbs tuberculate.

The main diagnostic characters of $S$. ruizi are the absence of discs on fingers, presence of small discs on toes, areolate ventral skin, conical tubercles on upper eyelid, lateral fringes on toes and presence of tarsal fold (Lynch 1981). Strabomantis ruizi is morphologically similar to Strabomantis necopinus (Lynch, 1997), yet it can be differed by the presence of a median otic plate (absent in $S$. necopinus) and the absence of discs on fingers (present in $S$. necopinus); moreover, their geographic ranges do not overlap (Lynch 1997; Castro-H and Bolívar-G 2010).

Strabomantis ruizi is restricted to the Andean Cordillera Occidental of Colombia (Castro-H and Vargas-Salinas 2008), where it has been reported from four localities in the department of Valle del Cauca, in the municipalities of Dagua, La Cumbre, Restrepo and Yotoco, all in the department of Valle del Cauca at elevations between 1500 and $2000 \mathrm{~m}$ above sea level (Lynch 1997).

An adult female, Strabomantis ruizi (CD-UV 1882; SVL $=67.8 \mathrm{~mm}$ ) was collected at Reserva "Costa Rica", Hacienda Campo Alegre, Vereda Arauca, Corregimiento Andinápolis, municipality of Trujillo, department of Valle del Cauca, Colombia (04¹0’32" N, 76²4'15” W, 1800 m) on 11 October 2009 at $c a .15: 30$ h, in a disturbed forest, next to La Capota river. A juvenile male (CD-UV 1916; SVL $=33.9 \mathrm{~mm}$ ) was collected along the basin of Meléndez river, Vereda El Minuto, Corregimiento Villacarmelo, municipality of Santiago de Cali, department of Valle del
Cauca, Colombia (03²3'33" N, 76³5'34" W, 1500 m) on 10 January 2010 at $c a$. 19:30 h, inside an advanced secondary forest. Strabomantis ruizi was found in sympatry with Pristimantis cf. achatinus (Boluenger, 1898), P. brevifrons (Lynch, 1981), P. erythropleura (Boulenger, 1896), $P$. palmeri (Boulenger, 1912) and Colostethus fraterdanieli (Silverstone, 1971) at Reserva Costa Rica; and with $P$. palmeri, P. erythropleura, P. orpacobates (Lynch, RuízCarranza and Ardila-Robayo, 1994), P. brevifrons and Cochranella savagei (Ruiz-Carranza and Lynch, 1991) at the Meléndez river basin. Specimens are deposited at the Colección de Docencia de Vertebrados, Sección de Zoología, Departamento de Biología, Universidad del Valle, Cali, Colombia.

Localities reported herein correspond to the southernmost and northernmost records of $S$. ruizi in the department of Valle del Cauca, both on the eastern slope of the Cordillera Occidental, extending the species

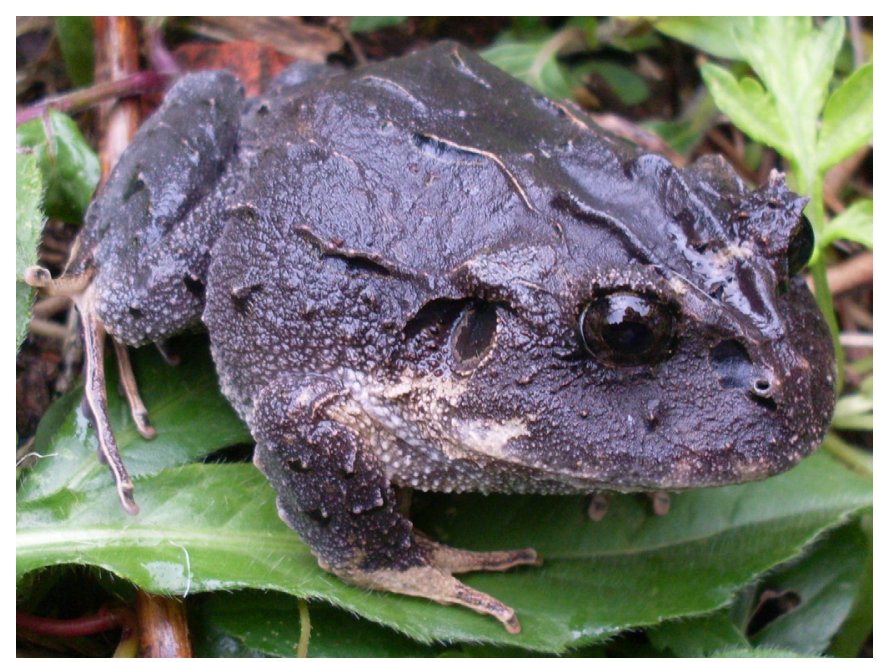

FIgURE 1. An adult female of Strabomantis ruizi (CD-UV 1882) from Reserva "Costa Rica", Hacienda Campo Alegre, Vereda Arauca, Corregimiento Andinápolis, municipality of Trujillo, department of Valle del Cauca, Colombia. Photo by Ana Paola Yusti-Muñoz. 


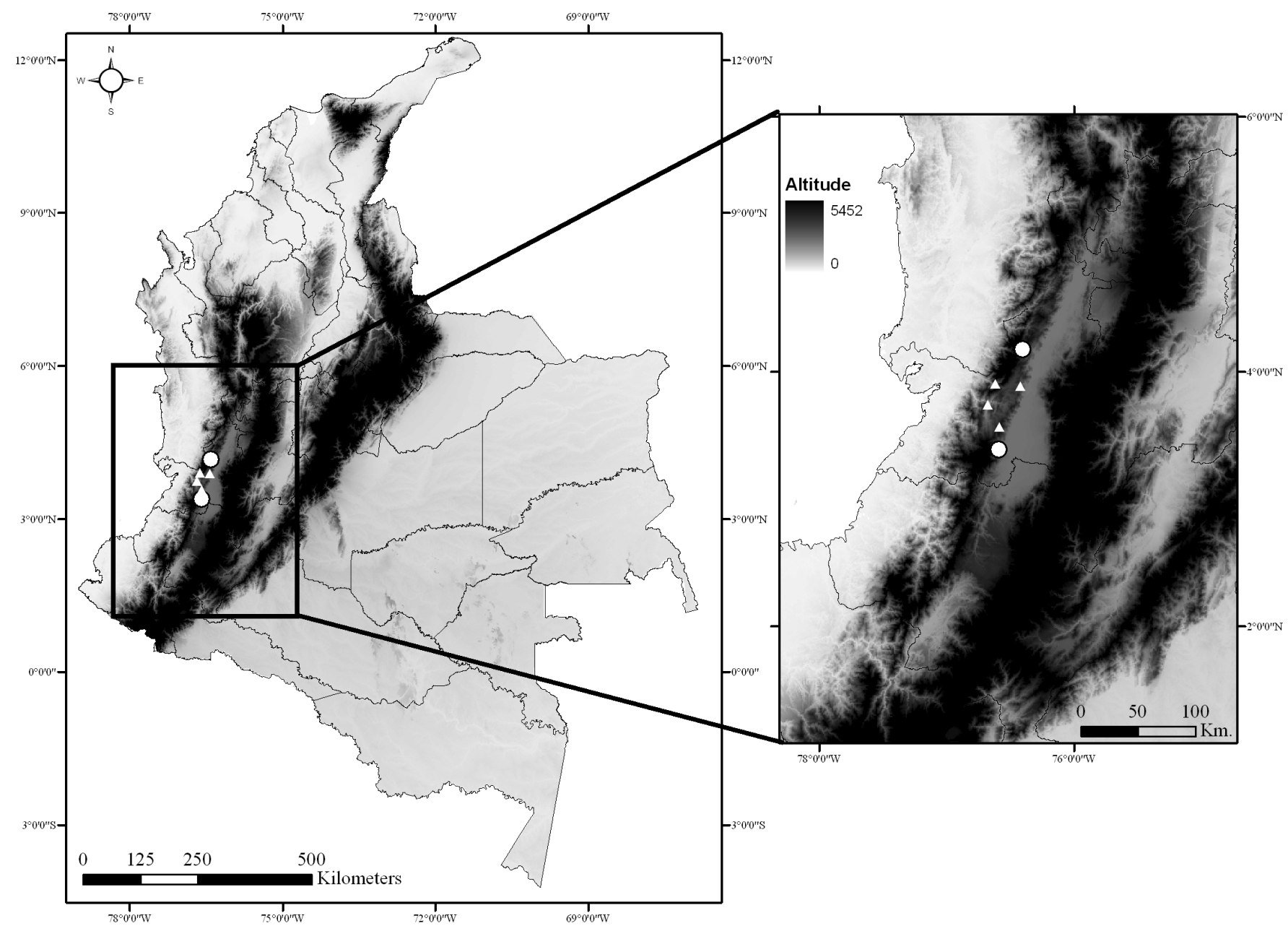

FIGURE 2. Map of western Colombia, showing locality records for Strabomantis ruizi. Enlarged map on the right shows detail new localities (white dots) and historical locations (white triangles) by Lynch (1997).

distribution ca. $31 \mathrm{~km} \mathrm{~N}$ and $21 \mathrm{~km} \mathrm{~S}$ (straight-line distance) from the previous localities (Lynch 1997) (Figure 2).

Strabomantis ruizi is an uncommon species in the places where it is found. It is believed that populations are decreasing, and characteristics as its relative big size in addition to small populations, make the species highly sensitive to human disturbance, mainly to the effects of agriculture and human settlements. Globally, the species is listed as Endangered; according to Castro-H. and Bolívar-G. (2010), the population of the type locality is the only one that is actually protected. The species has been reported as positive for Batrachochytrium in the same place (Castro- $\mathrm{H}$ et al. 2004; Velásquez-E et al. 2008). The discovery of this species in two new localities is of great importance to efforts aiming its conservation: the first locality, Reserva "Costa Rica", is part of the buffer area of the "Parque Natural Regional Páramo del Duende". The second locality, the Basin of Meléndez River, is part of the buffer area of the "Parque Nacional Natural Farallones de Cali".

ACKNOWLEDGMENTS: We are grateful to Leonardo Valencia for his company and hospitality during fieldwork time in Reserva "Costa Rica"; to Adriana Lucía Guerrero-Chacón for her invaluable assistance in the map elaboration; to Javier Méndez-Narváez and the referees for their commentaries and help to improve the manuscript but especially to Diego F. Cisneros-Heredia and Henrique Costa (Check List editors); and to the academic program of Biology of Universidad del Valle for the opportunity to undertake fieldwork that led to this report.

\section{Literature Cited}

Castro-H, F., M.I. Herrera and J. Lynch. 2004. Strabomantis ruizi. IUCN Red List of Threatened Species. Electronic Database accessible at http:// www.iucnredlist.org. Captured on 19 January 2011.

Castro-H, F., W. Bolívar-G and M.I. Herrera-M. 2007. Guía de los Anfibios y Reptiles del Bosque de Yotoco, Valle del Cauca, Colombia. Cali: Grupo de Investigación Laboratorio de Herpetología, Universidad del Valle. $70 \mathrm{p}$.

Castro-H, F. and F. Vargas-Salinas. 2008. Anfibios y reptiles en el departamento del Valle del Cauca, Colombia. Biota Colombiana 9(2): 251-277.

Castro-H, F. and W. Bolívar-G. 2010. Libro Rojo de los Anfibios del Valle del Cauca. Cali: Feriva Impresores SA. 200 p.

Lynch, J.D. 1981. The Systematic Status of Amblyphrynus ingeri (Amphibia: Leptodactylidae) with the Description of an Allied Species in Western Colombia. Caldasia 13(62): 313-332.

Lynch, J.D. 1997. Intrageneric relationships of mainland Eleutherodactylus II. A review of the Eleutherodactylus sulcatus group. Revista de la Academia Colombiana de Ciencias Exactas Físicas y Naturales 21(80): 353-372.

Velásquez-E, B., F. Castro-H, W. Bolívar-G and M.I. Herrera. 2008. Infección por el hongo quítrido Batrachochytrium dendrobatidis en la Cordillera Occidental de Colombia. Herpetotropicos 4(2): 65-70.

RECEIVED: May 2011

LAST REVISED: August 2011

ACCEPTED: August 2011

PuBlished ONLINE: October 2011

EDITORIAL RESPONSIBILITY: Diego Francisco Cisneros-Heredia 